\title{
Risk Factors Associated with Preterm Birth at Hasan Sadikin General Hospital in 2015
}

\author{
Zulvayanti Zulhamdi Hidayat' ${ }^{1}$ Eris Abdul Ajiz², Achadiyani ${ }^{3}$, Sofie Rifayani Krisnadi4* \\ ${ }^{1}$ Department of Obstetrics and Gynecology, Faculty of Medicine, Universitas Padjadjaran/Hasan Sadikin General Hospital, Bandung, \\ Indonesia \\ ${ }^{2}$ Faculty of Medicine, University of Padjadjaran, Bandung, Indonesia \\ ${ }^{3}$ Department of Biology Cell, Faculty of Medicine, University of Padjadjaran, Bandung, Indonesia \\ ${ }^{4}$ Reproductive Health Study Center, Universitas Padjadjaran, Bandung, Indonesia \\ Email: ${ }^{\star}$ wgrepro.health@unpad.ac.id
}

How to cite this paper: Hidayat, Z.Z., Ajiz, E.A., Achadiyani and Krisnadi, S.R. (2016) Risk Factors Associated with Preterm Birth at Hasan Sadikin General Hospital in 2015. Open Journal of Obstetrics and Gynecology, 6, 798-806.

http://dx.doi.org/10.4236/ojog.2016.613098

Received: October 6, 2016

Accepted: December 3, 2016

Published: December 6, 2016

Copyright $\odot 2016$ by authors and Scientific Research Publishing Inc. This work is licensed under the Creative Commons Attribution International License (CC BY 4.0).

http://creativecommons.org/licenses/by/4.0/

(c) (i) Open Access

\begin{abstract}
Background: Preterm birth defined as childbirth occurring at less than 37 completed weeks or 259 days of gestation. The causes of preterm birth are complex and multifactorial, many risk factors that contribute in it. Knowledge of risk factors is crucial for predicting the incidence of preterm births. This study aimed to determine the factors associated with preterm birth at the Hasan Sadikin General Hospital. Method: This study was a cross-sectional analytic using secondary data. Data derived from medical records maternity patients in the Department of Obstetrics and Gynecology Hasan Sadikin General Hospital taken in 2015. 1944 patients' medical records who gave birth met the inclusion criteria. Data analyses used were bivariate (chi square) and multivariate (logistic regression). Result: The result showed that the variables including age $(p=0.043, \mathrm{OR}=1.586)$, antenatal care $(p<0.001, \mathrm{OR}=1.865)$, history of preterm birth $(p<0.001$, OR $=2.337)$, anemia $(p<0.001$, OR $=1.307)$, hypertension $(p<0.001, \mathrm{OR}=3.969)$, and antepartum hemorrhage $(p<0.001, \mathrm{OR}=6.917)$ had significant result $(p<0.05)$. Among these variables, antepartum hemorrhage held the strongest correlation with the preterm birth. Conclusion: There is a significant relationship between age, antenatal care, preterm birth history birth, anemia, hypertension, and antepartum hemorrhage with preterm birth as risk factors.
\end{abstract}

\section{Keywords}

Preterm Birth, Hasan Sadikin General Hospital

\section{Introduction}

Preterm birth is defined as childbirth that occurring at gestational age less than 37 
weeks (259 days) from the first day of last menstruation. Preterm birth is still a major cause of morbidity and mortality in perinatal [1]. Babies born prematurely have increased risks of neurological developmental disorders such as severe cerebral palsy, mental retardation, sensory disturbances (impaired vision, hearing impairment) and hydrocephalus, or problems like learning difficulties, language, impaired concentration or attention, hyperactivity, motor disabilities, and cognitive problems. About one fifth of babies born under 32 weeks of age cannot survive the first year compared with $1 \%$ of deaths of infants born at the age of 33 - 36 weeks and only about $0.3 \%$ of infant deaths when the birth was at sufficient months [2] [3].

The incidence of preterm birth varies. Blencowe, H. et al., reported that in 2010 the number of preterm birth worldwide reached 15 million, with 11 countries in the world that has a number of preterm births more than 15 per 100 live births. In Europe, the figure ranges between $5 \%-11 \%$ [3]. In the USA, one of the nine infants was born preterm (11.9\%) as a result of spontaneous labor and maternal indications, [4] and in Australia it happened about $7 \%$. Although in developed countries early detection, prevention, management of preterm birth are well managed, however there has been a little increase in incidence as due to the increase of female labor force in the last decade; in which currently happening in Indonesia. In developing countries, the incidence is much higher, about $30 \%$ in India, $15 \%$ in South Africa, $31 \%$ in Sudan and $10 \%$ in Malaysia. Indonesia ranks fifth country with the highest preterm birth in the world after India, China, Nigeria, and Pakistan [4]. In Indonesia, the record of the incidence of preterm birth nationwide is not yet available, but the incidence of babies with low birth weight (LBW) might reflect a rough indication of preterm births; hospitals nationwide figure is $27.9 \%$, the provincial rate varies from $7.2 \%$ to $16.8 \%$ with the average rate of $10.2 \%$, while West Java is $10.8 \%$ [5].

The cause of preterm birth is complex and multifactorial. Several factors are expected to increase the risk of the incidence of premature birth, including maternal age, education, parity, pregnancy interval, preterm birth history, history of abortion, premature rupture of membranes (PROM), antepartum hemorrhage, antenatal care, and maternal diseases, for example hypertension, anemia and even some of preterm births that occurred spontaneously did not show apparent risk factors [6]. Knowledge of risk factors is crucial for predicting the incidence of preterm birth in order to reduce the incidence of premature childbirth. This study aimed to analyze the factors associated with preterm births at the Hasan Sadikin General Hospital in 2015. The result is expected to be a source of information for health professionals and the public about the risk factors for preterm birth so that prevention and early detection can be done more effectively.

\section{Methods}

This study was conducted with the approval of the Ethics Committee of Hasan Sadikin General Hospital. This research method is cross sectional with chi square bivariate and multivariate logistic regression. The research instrument is secondary data derived from medical records of patients registered in Maternal Perinatal Registration Indone- 
sia (MPRI) Department of Obstetrics and Gynecology Hasan Sadikin General Hospital in 2015. The study was conducted between May to June 2016 at the Department of Obstetrics and Gynecology Hasan Sadikin General Hospital.

The number of samples in this study is 1944. Inclusion criteria for this study is the patients' medical record that contains information about the gestational age at delivery, maternal age, education, antenatal care, parity, pregnancy interval, preterm birth history, history of abortion, anemia, hypertension, antepartum hemorrhage, and premature rupture of membranes. The exclusion criteria are those patients with incomplete medical records.

Dependent variable in this research is preterm birth. There are eleven independent variables analyzed in this study include age, education, parity, hypertension, anemia, preterm birth history, history of abortion, antepartum hemorrhage, premature rupture of membranes (PROM), antenatal care, and pregnancy interval.

Stages bivariate analysis begins with chi square between each independent variable and the dependent variable. Furthermore, the variable has a value of $\mathrm{p}<0.05$ included in the multivariate logistic regression analysis with the method of selection. The results of the analysis were considered statistically significant if $\mathrm{p}<0.05$.

\section{Result}

1944 of 2024 patients' medical records who gave birth at Hasan Sadikin General Hospital in 2015 met the inclusion criteria, consisted of 680 patients who experience preterm birth and 1264 of patients with normal birth. It shows 35\% of preterm birth occurred at the Hasan Sadikin General Hospital in 2015.

Analysis shows that the majority of subjects in this study were patients with productive age group (20 - 35 Year). By education level, subjects with primary school as the highest education has a greater proportion compared to the group of patients with full term (67.7\%). Based on the intensity of antenatal care, patients who received less than 4 times antenatal care $(52.3 \%)$ belong in the group of preterm birth. More than $50 \%$ of the subjects of this study are multiparous patients. Distribution of patients based on pregnancy interval (54\%), majority $\geq 24$ months; while the rest $(3.9 \%)$ less than 24 months and $43.3 \%$ is the first pregnancy. The proportion of patients with preterm birth (54.8\%) is greater than patients with sufficient birth months (45.2\%) in the group of patients with history of preterm birth. With or without a history of abortion, full term patients are greater in proportion to patients with preterm birth.

In this study, distribution of patients who experienced anemia in preterm birth group is $42.1 \%$ compared to $57.9 \%$ in the group with sufficient birth months. Patients with hypertension are $25.8 \%$, as preeclampsia is known as the most common type of hypertension. Greater proportion of antepartum hemorrhage occurred in patients with preterm birth (75.2\%) compared with patients in the sufficient birth months (24.8\%). The percentage of patients with premature rupture is $66.1 \%$ and the majority occurs during labor at full term. Distribution of the complete patient characteristics can be seen in Table 1 . 
Table 1. Distribution characteristics in patients maternity at Hasan Sadikin general hospital in 2015.

\begin{tabular}{|c|c|c|c|c|c|c|}
\hline \multirow{3}{*}{ Variable } & \multicolumn{4}{|c|}{ Preterm birth } & \multirow{3}{*}{ Total n (\%) } & \multirow{3}{*}{$p$-valuc } \\
\hline & \multicolumn{2}{|c|}{ Yes } & \multicolumn{2}{|c|}{ No } & & \\
\hline & $\mathbf{N}$ & $(\%)$ & $\mathbf{n}$ & $(\%)$ & & \\
\hline \multicolumn{7}{|l|}{ Age } \\
\hline$<20$ year & 86 & 42.8 & 115 & 57.2 & $201(10.3)$ & \multirow{3}{*}{0.043} \\
\hline 20-35 year & 469 & 34.4 & 894 & 65.6 & $1363(70.1)$ & \\
\hline$>35$ year & 125 & 32.9 & 255 & 67.1 & $380(19.6)$ & \\
\hline \multicolumn{7}{|l|}{ Education } \\
\hline Elementary School & 126 & 32.3 & 264 & 67.7 & $390(20.1)$ & \multirow{4}{*}{0.217} \\
\hline Middle School & 228 & 37.7 & 377 & 62.3 & $605(31.1)$ & \\
\hline High School & 218 & 35.6 & 395 & 64.4 & $613(31.5)$ & \\
\hline University & 108 & 32.1 & 228 & 67.9 & $336(17.3)$ & \\
\hline \multicolumn{7}{|l|}{ Antenatal care } \\
\hline$<4$ times & 68 & 52.3 & 62 & 47.7 & $130(6.7)$ & \multirow[t]{2}{*}{$<0.001$} \\
\hline$\geq 4$ times & 612 & 33.7 & 1202 & 66.3 & $1,814(93.3)$ & \\
\hline \multicolumn{7}{|l|}{ Parity } \\
\hline Primipara & 299 & 35.6 & 542 & 64.4 & $841(43.3)$ & \multirow{2}{*}{0.381} \\
\hline Multipara & 360 & 35.1 & 667 & 64.9 & $1,027(52.8)$ & \\
\hline Grande Multipara & 21 & 27.6 & 55 & 72.4 & $76(3.9)$ & \\
\hline \multicolumn{7}{|l|}{ Pregnancy Interval } \\
\hline$<24$ months & 54 & 37.5 & 90 & 62.5 & $144(7.4)$ & \multirow{2}{*}{0.759} \\
\hline$\geq 24$ months & 362 & 35.1 & 669 & 64.9 & $1031(53)$ & \\
\hline First pregnancy & 264 & 34.3 & 505 & 65.7 & $769(39.6)$ & \\
\hline \multicolumn{7}{|c|}{ Labor Histories Preterm birth history } \\
\hline Yes & 74 & 54.8 & 61 & 45.2 & $135(6.9)$ & \multirow[t]{2}{*}{$<0.001$} \\
\hline No & 606 & 33.5 & 1203 & 66.5 & $1809(93.1)$ & \\
\hline \multicolumn{7}{|l|}{ History of abortion } \\
\hline Yes & 101 & 37.1 & 171 & 62.9 & $272(14)$ & \multirow[t]{2}{*}{0.422} \\
\hline No & 579 & 34.6 & 1093 & 65.4 & $1672(86)$ & \\
\hline \multicolumn{7}{|l|}{ Anemia } \\
\hline Yes & 195 & 42.1 & 268 & 57.9 & $463(23.8)$ & \multirow[t]{2}{*}{$<0.001$} \\
\hline No & 485 & 32.7 & 996 & 67.3 & $1481(76.2)$ & \\
\hline \multicolumn{7}{|l|}{ Hypertension } \\
\hline No hypertension & 483 & 33.5 & 959 & 66.5 & $1442(74.2)$ & \\
\hline Gestational hypertension & 16 & 17.4 & 76 & 82.6 & $92(4.7)$ & $<0001$ \\
\hline Preeclampsia & 137 & 46 & 161 & 54 & $298(15.3)$ & $<0.001$ \\
\hline Eclampsia & 30 & 66.7 & 15 & 33.3 & $45(2.3)$ & \\
\hline Chronic hypertension & 14 & 20.9 & 53 & 79.1 & $67(3.4)$ & \\
\hline Antepartum hemorrhage & & & & & & \\
\hline Yes & 76 & 75.2 & 25 & 24.8 & $101(5.2 \%)$ & $<0.001$ \\
\hline No & 604 & 24.8 & 1239 & 67.2 & $1843(94.8)$ & \\
\hline PROM & & & & & & \\
\hline Yes & 107 & 33.9 & 209 & 66.1 & $316(16.3)$ & 0.649 \\
\hline No & 573 & 35.2 & 1055 & 64.8 & $1628(83.7)$ & \\
\hline Total & 1264 & 65 & 680 & 35 & 1944 & \\
\hline
\end{tabular}


The results of the bivariate analysis between each independent variable with preterm birth shows that the variables age, antenatal care, preterm birth history, anemia, hypertension and antepartum hemorrhage have a significant result $(p<0.05)$. Variables that showed significant results included in the logistic regression.

Multivariate analysis to look at simultaneous relationship between independent variables and the dependent variable in Table 2 shows that variables that have the strongest association with preterm birth is antepartum hemorrhage with a value of $p=$ $0.000(<0.05)$ and the odds ratio (OR) amounted to 6.917 (4.270 to 11.205 IK95\%), meaning that patients with antepartum hemorrhage 6.917 times are more likely to experience preterm birth compared to patients who did not go through antepartum hemorrhage.

\section{Discussion}

The results of this study indicate that maternal age factor has a significant relationship to preterm birth. Pregnant patients with age $<20$ years are 1586 times likely to experience preterm birth compared to the age group of 20 - 35 years. The results are consistent with the research conducted by Kozuki et al., which states that women with age $<20$ years is the category that has the highest risk for the occurrence of labor premature [7]. Pregnancies at young age are more likely to experience complications during pregnancy and childbirth because young women often have limited knowledge about pregnancy or lack of information on how to access the health care system. At this age, they also have not reached physical maturity, mental and reproductive organs function to be the prospective mother. The likelihood of stress on pregnant women at young age is very high, thus the levels of catecholamine and cortisol levels could increase which then enable the placental corticotrophin releasing hormone and precipitate labor through biological pathway [8].

Table 2. Relationship variables with genesis preterm birth.

\begin{tabular}{ccccc}
\hline Variable & OR & \multicolumn{3}{c}{ IK 95\% } \\
\cline { 3 - 4 } Age & & Min & Max & \\
$<20$ & 1.586 & 1.159 & 2.171 & 0.004 \\
$20-35$ & - & - & - & - \\
$>35$ & 0.786 & 0.603 & 1.025 & 0.076 \\
Antenatal care & 1.865 & 1.276 & 2.725 & $<0.001$ \\
Preterm birth history & 2.337 & 1.613 & 3.387 & $<0.000$ \\
Anemia & 1.307 & 1.039 & 1.643 & 0.022 \\
Hypertension & & & & \\
No hypertension & - & - & - & $<0.001$ \\
Gestational hypertension & 0.467 & 0.267 & 0.818 & 0.008 \\
Preeclampsia & 1.846 & 1.416 & 2.406 & $<0.001$ \\
Eclampsia & 3.969 & 2.088 & 7.544 & $<0.001$ \\
Chronic hypertension & 0.545 & 0.287 & 1.034 & 0.063 \\
Antepartum hemorrhage & 6.917 & 4.270 & 11.205 & $<0.001$ \\
\hline
\end{tabular}


Antenatal care variables showed significant results. Patients who received antenatal care $<4$ times are 1.865 times greater chance to experience premature birth compared to patients undergoing antenatal $\geq 4$ times. Something similar is described by Mahapula FA et al., that antenatal care had a significant association with preterm birth as a risk factor [9]. Performed at least 4 times, one in the first trimester, one in the second trimester, and 2 times in third trimester. Some of activities carried out on antenatal care include maternal health checks on regular basis, provision of TT (Tetanus Toxoid), iron tablets, tests for sexually transmitted diseases and counseling, in order to prevent and conduct early detection of preterm birth [10].

The history of premature birth is significantly associated with the incidence of preterm birth and as a risk factor. Results in this study are consistent with the research conducted by G.C. Di Renzo et al., stating that patients with a history of previous preterm delivery have amounted to 3412 times of the possibility to experience preterm birth compared to patients without a history of premature birth [11].

Anemia has a significant relationship with the occurrence of preterm birth as a risk factor. This is consistent with studies conducted by Yi, Han, \& Ohrr in Korea which conclude that anemia in pregnant women contributes 1.53 times against premature birth. In pregnant women with anemia, disruption delivery of oxygen and nutrients from the mother to the placenta and fetus, affecting the function of the placenta. Anemia in pregnant women other than can lead to impaired fetal growth, can also cause abortion, obstructed labor, puerperal sepsis, prematurity and maternal, even fetus mortality [12]. During pregnancy, the mother's body undergoes many changes one of which is the relationship between blood supply and the body's response. Total number of plasma in pregnant women and the number of red blood cells increased from the initial needs, but the increase in the volume of plasma is greater than the increase in the mass of red blood cells. This causes a decrease in hemoglobin concentration, thus affecting the levels of $\mathrm{O}_{2}$ into the network. This situation may cause tissue hypoxia that will then produce cortisol and prostaglandins, which trigger preterm birth in women with anemia [8].

In this study, hypertension showed a significant result with the incidence of preterm birth as a risk factor. This relationship is also described in the research Xiong et al., reported that there is a significant correlation between the incidence of preeclampsia and premature birth [13]. Fetus conceived by mothers with preeclampsia can potentially cause premature birth. In women with preeclampsia or eclampsia, "spiral arteries remodeling" failures occurred causing placental ischemia and endothelial dysfunction. Arterioles spasm of blood vessels leading to important organs in the body can narrow the blood flow to retro-placenta resulting disruption changes of $\mathrm{CO}_{2}, \mathrm{O}_{2}$ and nutrients to the fetus. This causes vasospasm and hypovolemic, thus the fetus becomes hypoxic and malnutrition. Hypoxia causes placental transfer with high levels of cortisol into the fetal circulation. High cortisol concentration is prostacyclin, which will synthesize prostaglandin (PGE-2) and cause contraction; therefore, babies are often born prematurely [14]. 
Antepartum hemorrhage also had a significant relationship with the occurrence of preterm birth as a risk factor with $\mathrm{OR}=6.835$ Most serious in the multivariate analysis. $\mathrm{H}$. Lestari on research states that antepartum hemorrhage is one risk factor for preterm birth and generally occurs in multiparous parity with common causes of placenta previa and abruption plasenta [15]. In this study, more than $50 \%$ of the study are patients with parity multiparas so will increase the risk antepartum hemorrhage. Antepartum hemorrhage is a life-threatening obstetric emergency maternal and fetal. Pregnancy with recurrent bleeding despite the pregnancy to be terminated not enough months [16].

This research conclusion is not significant to the parity factor. The results of this study are differ from Kartikasari's research that suggests that multipara is a risk factor for preterm birth with Odd Ratio $=3.28$ [17]. While according Yanniarti et al., mothers with grandemultipara 1.9 times likely to experience obstructed labor premature [18]. Other research supported this research is Wijayanti et al. which stated that there was no correlation between maternal parity with the incidence of preterm birth at the Hospital PantiWilasaCitarum in 2010 [19].

Based on pregnancy interval, the statistical results showed there was no significant association with the preterm births that have $p>0.05$. The results of this study are not consistent with the study conducted by DeFranco, stating that the spacing pregnancies of $<6$ months increased the risk of preterm birth 2.19 times; $6-12$ months increased the risk of preterm birth by 1.36 times; and 1.02 times for mothers with pregnancy within 12 - 18 months. Possible causes are not significant due to the different grouping of the subjects. In this study, the subjects were sorted by the first pregnancy, pregnancy interval $<24$ months and pregnancy interval of $\geq 24$ months [20].

Premature rupture of membranes (PROM) in this study showed no significant results, in contrast with the research conducted by Purwahati et al. (2014) which states that there is a significant relationship between the PROM with the incidence of preterm birth at the Mutiara Bunda Maternity Hospital Salatiga; with preterm birth occurs in women who had premature rupture of membranes (63.6\%) than women who did not go through premature rupture of membranes (3.0\%) [21]. The procedure at Hasan Sadikin General Hospital to patients with preterm PROM will be treated conservatively for 2 days. If a patient has an infection then the pregnancy will be terminated, but if there are no signs of infection, the patient is allowed to go home. Such procedures make these results were not significant because not all patients with PROM can be fully analyzed.

Based on educational level of maternity patients at Hasan Sadikin Hospital, there was no significant correlation with preterm birth $(p=0.217)$, the proportion of subjects in the group of preterm patients $(67.7 \%)$ was higher in patients with primary school education compared to patients with middle and high school education. This is consistent with the statement from Anini Sarhan A L H E analysis of data taken from three government hospitals in the Northern West Bank, stated that there is no significant relationship between education and preterm birth, thus education is not perceived as a risk 
factor for preterm birth. It was found that $3 \%$ of all preterm births occurred in patients with education levels $<6$ years and $74 \%$ in patients with secondary level education $6-12$ years) [22].

In this study, a history of abortion showed no significant results with $\mathrm{p}=0.422(\mathrm{p}>$ 0.05) which is supported by Alijahan et al. (2014). In his research, on the prevalence and risk factors associated with preterm birth in Ardabil, Iran, stating that the history of abortion does not affect preterm birth significantly and cases of preterm births found more in patients who do not have history of abortion (80\%) [23].

This study has several limitations, for example, not all variables expected to be related to the incidence of preterm births were analyzed, such as the presence or absence of infection, occupation, behavior and psychosocial state of the patients, since the analyzed data were merely obtained from the medical records. In addition, there are several variables that cannot be analyzed completely such as the rupture of the membranes.

\section{Conclusion}

The conclusion of this study indicates that factors associated with preterm birth at Hasan Sadikin General Hospital in 2015 include age, antenatal care, history of preterm birth, anemia, hypertension, and antepartum hemorrhage. Antepartum hemorrhage is the most significant factor associated with premature delivery.

\section{References}

[1] Liu, L., Johnson, H.L., Cousens, S., Perin, J., Scott, S., Lawn, J.E., Rudan, I., Campbell, H., Cibulskis, R., Li, M., Mathers, C. and Black, R.E. (2012) Global, Regional, and National Causes of Child Mortality: An Updated Systematic Analysis for 2010 with Time Trends since 2000. The Lancet, 379, 2151-2161. http://dx.doi.org/10.1016/S0140-6736(12)60560-1

[2] Soleimani, F., Zaheri, F. and Abdi, F. (2014) Long-Term Neurodevelopmental Outcomes after Preterm Birth. Iranian Red Crescent Medical Journal, 16, e17965. http://dx.doi.org/10.5812/ircmj.17965

[3] Bhutta, A.T., Cleves, M.A., Casey, P.H., Cradock, M.M. and Anand, K. (2002) Cognitive and Behavioral Outcomes of School-Aged Children Who Were Born Preterm: A Meta-Analysis. JAMA, 288, 728-737. http://dx.doi.org/10.1001/jama.288.6.728

[4] Blencowe, H., Cousens, S., Oestergaard, M.Z., Chou, D., Moller, A.-B., Narwal, R., Adler, A., Garcia, C.V., Rohde, S., Say, L. and Lawn, J.E. (2012) National, Regional, and Worldwide Estimates of Preterm Birth Rates in the Year 2010 with Time Trends since 1990 for Selected Countries: A Systematic Analysis and Implications. The Lancet, 379, 2162-2172. http://dx.doi.org/10.1016/S0140-6736(12)60820-4

[5] Kemenkes, R.I. (2015) Profil Kesehatan Indonesia Tahun 2014. Jakarta.

[6] Xu, H., Dai, Q., Xu, Y., Gong, Z., Dai, G., Ding, M., Duggan, C., Hu, Z. and Hu, F.B. (2015) Time Trends and Risk Factor Associated with Premature Birth and Infants Deaths Due to Prematurity in Hubei Province, China from 2001 to 2012. BMC Pregnancy and Childbirth, 15, 1. http://dx.doi.org/10.1186/s12884-015-0767-x

[7] Kozuki, N., Lee, A.C., Silveira, M.F., Sania, A., Vogel, J.P., Adair, L., et al. (2013) The Associations of Parity and Maternal Age with Small-for-Gestational-Age, Preterm, and Neonatal and Infant Mortality: A Meta-Analysis. BioMed Central Public Health, 13, 1-10.

[8] Suspimantari, C. and Pramono, B.A. (2014) Factors That Influence the Risk of Prematurity 
against Maternal and Perinatal Outcomes by Gestational Age in the Case Study RSUP Dr. Kariadi Semarang Tahun 2013: Faculty of Medicine Diponegoro University.

[9] Mahapula, F.A., Kumpuni, K., Mlay, J.P. and Mrema, T.F. (2015) Risk Factors Associated with Pre-Term Birth in Dar es Salaam, Tanzania: A Case-Control Study. Tanzania Journal of Health Research, 18.

[10] Depkes, R.I. (2007) Pedoman Pelayanan Antenatal. Jakarta.

[11] Di Renzo, G.C., Giardina, I., Rosati, A., Clerici, G., Torricelli, M., Petraglia, F., et al. (2011) Maternal Risk Factors for Preterm Birth: A Country-Based Population Analysis. European Journal of Obstetrics \& Gynecology and Reproductive Biology, 159, 342-356. http://dx.doi.org/10.1016/j.ejogrb.2011.09.024

[12] Yi, S.W., Han, Y.J. and Ohrr, H. (2013) Anemia before Pregnancy and Risk of Preterm Birth, Low Birth Weight and Small-for-Gestational-Age Birth in Korean Women. European Journal of Clinical Nutrition, 67, 337-342. http://dx.doi.org/10.1038/ejcn.2013.12

[13] Xiong, X., Demianczuk, N., Saunders, D., Wang, F. and Fraser, W.D. (2002) Impact of Preeclampsia and Gestational Hypertension on Birth Weight by Gestational Age. American Journal of Epidemiology, 155, 203-209. http://dx.doi.org/10.1093/aje/155.3.203

[14] Ambarwati, W.N. (2009) Irdawati. Relations Preeclampsia Babies Born with the Condition as Sectio Caesarea in RSUD Dr. Moerwadi Surakarta. Berita Ilmu Keperawatan, 2, 1-6.

[15] Lestari, H. (2009) Hubungan antara paritas dengan kejadian perdarahan antepartum. Skripsi. Surakarta: Universitas Sebelas Maret, Program Studi Div Kebidanan Fakultas Kedokteran.

[16] Jain, S., Jain, N., Dahiya, P., Rohilla, S. and Malik, R. (2016) A Prospective Study of Maternal Outcome in Antepartum Haemorrhage in Tertiary Care Center in Northern India. International Journal of Reproduction, Contraception, Obstetrics and Gynecology, 5, 29-34. http://dx.doi.org/10.18203/2320-1770.ijrcog20151493

[17] Kartikasari, R.I. (2010) Hubungan faktor risiko multiparitas dengan persalinan preterm. Skripsi. Program Studi Div Kebidanan Fakultas Kedokteran, Universitas Sebelas Maret, Surakarta.

[18] Yanniarti, S., Ningsih, R. and Ferwita, S. (2013) Antepartum Haemorrhage Relationships and Birth Mothers Characteristics with Preterm Parturition Events in Hospitals M Yunus Bengkulu. Jurnal Kesehatan Poltekkes Provinsi Bengkulu, 1, 127-139.

[19] Wijayanti, M.D., Widjanarko, B. and Ratnaningsih, W. (2011) The Relationship of Age and Parity the Occurrence of Partus Prematurus in Panti Wilasa Citarum Hospital Semarang Year 2010. Jurnal Kebidanan Panti Wilasa, 2, 1-8.

[20] DeFranco, E.A., Stamilio, D.M., Boslaugh, S.E., Gross, G.A. and Muqlia, L.J. (2007) A Short Interpregnancy Interval Is a Risk Factor for Preterm Birth and Its Recurrence. American Journal of Obstetrics and Gynecology, 197, 264.e1-264.e6. http://dx.doi.org/10.1016/j.ajog.2007.06.042

[21] Purwahati, N.W.R., Mardiyaningsih, E. and Wulansari. (2014) The Relationship between Amniotic Premature Rupture with Preterm Labor at Mutiara Bunda Hospital Salatiga. Journal Ilmiah Ilmu-Ilmu Kesehatan, 17, 1-6.

[22] Sarhan, A.L. and Anini, H.E. (2015) Risk Factors of Preterm Birth among Palestinian Women: Case Control Study. Journal of Nursing Care Quality, 2, 1-8.

[23] Alijahan, R., Hazrati, S., Mirzaharimi, M., Pourfarzi, F. and Hadi, P.A. (2014) Prevalence and Risk Factors Associated with Preterm Birth in Ardabil, Iran. Iranian Journal of Reproductive Medicine, 12, 47-56. 
Submit or recommend next manuscript to SCIRP and we will provide best service for you:

Accepting pre-submission inquiries through Email, Facebook, LinkedIn, Twitter, etc. A wide selection of journals (inclusive of 9 subjects, more than 200 journals)

Providing 24-hour high-quality service

User-friendly online submission system

Fair and swift peer-review system

Efficient typesetting and proofreading procedure

Display of the result of downloads and visits, as well as the number of cited articles

Maximum dissemination of your research work

Submit your manuscript at: http://papersubmission.scirp.org/

Or contact ojog@scirp.org 